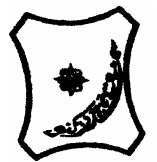

Bayero Journal of Pure and Applied Sciences, 9(1): 25 - 31

Received: May, 2016

Accepted: April, 2016

ISSN 2006 - 6996

\title{
EMERGENCE OF EBOLA VIRUS DISEASE AND ITS DEVASTATING IMPACT IN POOR-RESOURCED AREAS OF SUB-SAHARAN AFRICA
}

\author{
Azeez-Akande, 0. \\ Department of Medical Microbiology and Parasitology, College of Health Sciences, Bayero University, PMB 3011, \\ Kano-Nigeria \\ Email: aakande92@yahoo.com; +2348035893449
}

ABSTRACT

Ebola virus disease (EVD) is an unusual infection, and one of the most virulent emerging viral diseases known causing severe morbidity and significant mortality. In recent epidemic outbreak of EVD in West African countries of Guinea, Sierra Leone and Liberia (the 3 nations epi-centre of the epidemic), the disease has affected over 25,000 people resulting in more than 10,000 deaths, (Case Fatality Rate, CFR>40\%; i.e. from December, 2013-March, 2015). Following the first outbreak of EVD in Sudan and Democratic Republic of Congo (DRC) in 1976, several epidemics (>20 outbreaks) of the disease have been recorded particularly in poor-resourced areas of the East, Central and West-Africa resulting in significant mortality. CFR of EVD is 25-90 percent. Ebola virus is transmitted to humans by wild animals (mainly non-human primates) and spreads in human population via close contact with blood, body fluids and secretions of infected patients. EVD can also be acquired through direct contact with infected corpses. It is characterized (at initial stage) by non-specific flu-like symptoms including headache, fever, myalgia and malaise following incubation period of 2-21 days. This may terminate into severe systemic manifestations including diffuse internal and external bleeding, shock and death if untreated early. Non recognition of the specific natural host of Ebola virus and rapid progression of infection including slow mounting of acquired immunity against EVD by infected host complicate control measures. The socio-economic cost of EVD epidemic outbreak is colossal. Despite notable advances in healthcare-related technology enhancing the diagnosis, treatment / management and prevention / control of infectious or viral diseases, the response of the stakeholders over the years geared toward controlling the spread of the disease left much to be desired. No clinically certified drugs or vaccines against EVD are yet available. There is the urgent need by stakeholders to device appropriate preventive / control measures including development of effective drugs and vaccines to checkmate the spread of EVD and associated severe morbidity, high mortality and devastating socio-economic impact.

Key Words: Ebola virus disease, severe morbidity, mortality, socio-economic impact, checkmate.

\section{INTRODUCTION}

The Ebola Virus Disease (EVD) is an acute, highly infectious and immunosuppressive disease resulting in severe illness and significant mortality (Sanchez et al., 1996; WHO, 2012). Ebola virus was discovered in Sudan and Democratic Republic of Congo (DRC, formerly Zaire) in 1976 (Johnson et al., 1977; WHO, $1978 \mathrm{a}, \mathrm{b})$, and has, since then, been associated with major outbreaks of highly virulent epidemics of haemorrhagic fever in certain parts of Africa (Georges et al., 1999; WHO, 2003; WHO, 2012). Recent epidemic outbreaks (December 2013-March 2015) of the disease occurred in Guinea, Sierra Leone and Liberia (while Nigeria had a few cases of EVD), all in West Africa sub-region. Other areas that had recorded EVD epidemic outbreaks in the past include Gabon and Uganda (Peters et al., 1999; Brooks et al., 2004).
Human close contact with infected primate and fruit bats appears to be primary source of spread to human community (CDC, 1990; Fisher-Hoch et al., 1992).

Ebola virus disease epidemic outbreak poses a serious problem and a huge challenge to the health and socio-economic wellbeing of the people in poorresources areas of Africa. This may be attributed to poor medical infrastructure, inadequate manpower in healthcare sector, low capacity, and poor economic indices to tackle EVD epidemics. Generally, the culture of unpreparedness by the stakeholders and governments at all levels in many areas of developing countries of Africa contribute to aggravated Ebola epidemics and the usual slow pace of control of the outbreak witnessed in the region (WHO, 2012). 
The current effort is aimed at reviewing the regular outbreak of EVD and its devastating health and socioeconomic impact on African region. It is also aimed to sensitize the stakeholders on the imperativeness of checkmating the spread of the disease at this material time thus enhancing the socio-economic wellbeing and overall development of sub-Saharan region.

\section{Epidemiological Trend of Ebola Virus Disease}

Ebola virus disease (formerly known as Ebola Haemorrhagic Fever, EHF) has become an increasing burden in sub-Saharan areas of Africa causing significant morbidity, mortality and high socioeconomic cost (Georges et al., 1990; WHO, 2014). The World Health Organization (WHO, 2012) estimates that between 25 to $90 \%$ of all Ebola victims die from the disease (and may be up to $100 \%$ if the outbreak involves few cases) following infection.

Ebola was first noticed in 1976 during epidemic outbreaks which occurred at the same time in two remote villages of Nzara and Yambuku in Sudan Zaire (now Democratic Republic of Congo, DRC) respectively (Bowen et al., 1977; Johnson et al., 1977; WHO, 1978a, b). These areas are located near the tropical rain forests of sub-Saharan Africa. Yambuku village, one of the early epi-centres of EVD outbreaks is situated near the Ebola river which traverses the area and from which the disease derived its name (WHO, 2012). Over 600 people (602 victims) were affected in both cases with case fatality rate (CRF) of $71.6 \%$ (431 deaths), (WHO, 2014).

A second outbreak of EVD occurred in the same location of DRC in 1977 (One case resulting in one death (CFR, 100\%), and Sudan in 1979 affecting 34 people causing 22 deaths (CFR, 65\%; Table 1; WHO, 2014). Several other outbreaks of the disease (approx. 22 outbreaks) have been recorded in East Africa comprising DRC, Sudan, Uganda and Gabon including South Africa (Ex-Gabon) and Cote d' Ivoire (Ivory Coast) in West Africa (Table 1; WHO, 2014). In recent outbreak in West Africa sub-region, EVD has affected a large number $(>25,000)$ of the population; more than the cumulative total of Ebola victims ever recorded in the history of the disease. Ebola was first noticed (via fruit bat) in a remote village in Guinea Conakry in December, 2013 from where it is believed to have spread to Sierra Leone, Liberia and Nigeria (index case in Nigeria being a Liberian visitor, Patrick Sawyer) (FMH, 2014; WHO, 2015).

By the end of March, 2015, more than 25,000 cases of EVD have been reported causing over 10,000 deaths ( $>40 \%$ CFR) in the worst epidemic outbreak of the disease in recent history. Over 9 million children live in Ebola ravaged areas of the above 3 countries and $>5,000$ of them were directly affected. Over twenty percent of all Ebola cases were children and adolescents, and $80 \%$ of them were $<5$ years in age. Similarly, over 16,000 parents and care givers were severely affected by the epidemics while economic (running into millions of dollars) and educational/social activities were seriously jeopardized causing significant humanitarian disaster in the areas involved (WHO, 2015, UNICEF, 2015).

Table 1: Chronology of Ebola Virus Disease Outbreaks, 1977- March, 2015.

\begin{tabular}{|c|c|c|c|c|c|}
\hline Year & Country & Ebola virus Species & Cases & Deaths & Case Fatality \\
\hline $\begin{array}{l}\text { Dec, 2013- Mar, } \\
2015\end{array}$ & Guinea, Sierra Leone, Liberia & Not available & $>25,000$ & $\begin{array}{l}> \\
10,000\end{array}$ & $>40 \%$ \\
\hline 2014 & Nigeria & Not available & 18 & 8 & $44.4 \%$ \\
\hline 2012 & Democratic Republic of Congo & Bundibugyo & 57 & 29 & $51 \%$ \\
\hline 2012 & Uganda & Sudan & 7 & 4 & $57 \%$ \\
\hline 2012 & Uganda & Sudan & 24 & 17 & $71 \%$ \\
\hline 2011 & Uganda & Sudan & 1 & 1 & $100 \%$ \\
\hline 2008 & Democratic Republic of Congo & Zaire & 32 & 14 & $44 \%$ \\
\hline 2007 & Uganda & Bundibugyo & 149 & 37 & $25 \%$ \\
\hline 2007 & Democratic & Zaire & 264 & 187 & $71 \%$ \\
\hline 2005 & Congo & Zaire & 12 & 10 & $83 \%$ \\
\hline 2004 & Sudan & Sudan & 17 & 7 & $41 \%$ \\
\hline 2003 & Congo & Zaire & 35 & 29 & $83 \%$ \\
\hline Nov. 2003 & Congo & Zaire & 143 & 128 & $90 \%$ \\
\hline $\begin{array}{l}\text { Jan. 2001- April } \\
2002\end{array}$ & Congo & Zaire & 59 & 44 & $75 \%$ \\
\hline $2001-2002$ & Gabon & Zaire & 65 & 53 & $82 \%$ \\
\hline 2000 & Uganda & Sudan & 425 & 224 & $53 \%$ \\
\hline 1996 & SouthAfrica(ex- Gabon) & Zaire & 1 & 1 & $100 \%$ \\
\hline 1996 & Gabon & Zaire & 60 & 45 & $75 \%$ \\
\hline Jul - Dec. 1996 & Gabon & Zaire & 31 & 21 & $68 \%$ \\
\hline $\begin{array}{l}\text { Jan. } \\
1995\end{array}-$ April & Democratic Republic of Congo & Zaire & 315 & 254 & $81 \%$ \\
\hline 1994 & Cote d'Ivoire & Tai Forest & 1 & 0 & $0 \%$ \\
\hline 1994 & Gabon & Zaire & 52 & 31 & $60 \%$ \\
\hline 1979 & Sudan & Sudan & 34 & 22 & $65 \%$ \\
\hline 1977 & Democratic Republic of Congo & Zaire & 1 & 1 & $100 \%$ \\
\hline 1976 & Sudan & Sudan & 284 & 151 & $53 \%$ \\
\hline 1976 & Democratic Republic of Congo & Zaire & 218 & 280 & $88 \%$ \\
\hline
\end{tabular}

Formenty et al., 1999; FMH, 2014; WHO, 2012; 2014; 2015. 
Table 2: Epidemic Outbreak of Ebola Virus Disease in West Africa, December, 2013 - March, 2015.

\begin{tabular}{llll}
\hline & & No. of deaths as at: & \\
\hline & & $n=>25,000$ \\
$\begin{array}{l}\text { Country } \\
\begin{array}{l}\text { Guinea } \\
\text { Sierra Leone }\end{array}\end{array}$ & $6 / 01 / 2015$ & $30 / 3 / 2015$ \\
Liberia & 6,928 & 8,153 & $>10,000($ CFR,$>40 \%)$ \\
\hline WHO, 2015. & & & \\
\hline
\end{tabular}

Table 3: Ebola Outbreak in Nigeria, July - September, 2014

\begin{tabular}{lcccc} 
Location & $\begin{array}{c}\text { No. of Confirmed } \\
\text { Case }\end{array}$ & $\begin{array}{c}\text { Recorded Ebola Cases as at } 4^{\text {th }} \\
\text { No. Successfully } \\
\text { Managed and } \\
\text { Discharged }\end{array}$ & $\begin{array}{c}\text { Septer, 2014: } \\
\text { No. } \\
\text { Under } \\
\text { Surveillance }\end{array}$ & $\begin{array}{c}\text { No. of } \\
\text { Death/Case } \\
\text { Fatality Rate } \\
\text { (CFR) }\end{array}$ \\
\hline Lagos & 14 & 6 & 273 & 7 \\
Port Harcourt & 4 & 1 & 8 & 1 \\
Enugu & 0 & 0 & 14 & 0 \\
Ife & 0 & 0 & 1 & 0 \\
\hline Total (\%) & $\mathbf{1 8}$ & $\mathbf{7 ( 3 8 . 9 )}$ & $\mathbf{2 9 6}$ & $\mathbf{8 ( 4 4 . 4 )}$ \\
\hline
\end{tabular}

FMH, 2014.

Index case, Patrick Sawyer flew to Nigeria from Liberia on July 20, 2014.

\section{Classification and Properties of Ebola Virus}

Ebola virus is placed under the family, Filoviridae and Genus, Filovirus (thread-like). Other two genera categorized under this family are Marburg virus and Cueva virus. Morphologically, they are pleomorphic, long filamentous virions measuring about $80 \mathrm{~nm}$ and between $800 \mathrm{~nm}-1000 \mathrm{~nm}$ in length. However, those measuring up to $1,400 \mathrm{~nm}$ in length have been reported (Feldmann et al., 1994). Ebola virus particularly measures about 970nm while Marburg virus counterpart is about $790 \mathrm{~nm}$ in length. This shows that Ebola virus is longer and is characteristically bizarre-looking in appearance (Sanchez et al., 2001).

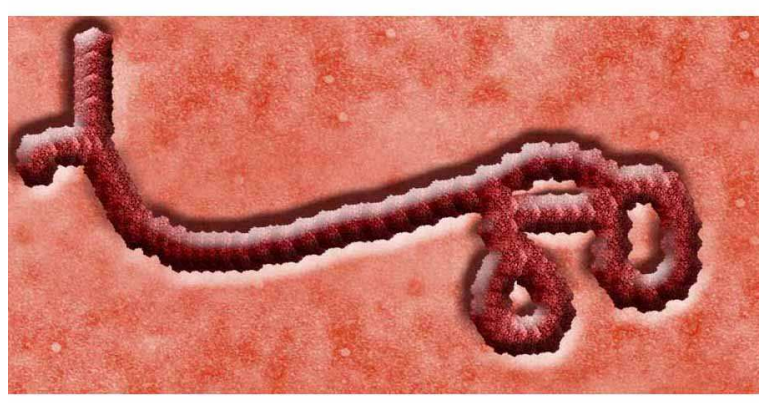

Ebola Virus (EPA, 2014)

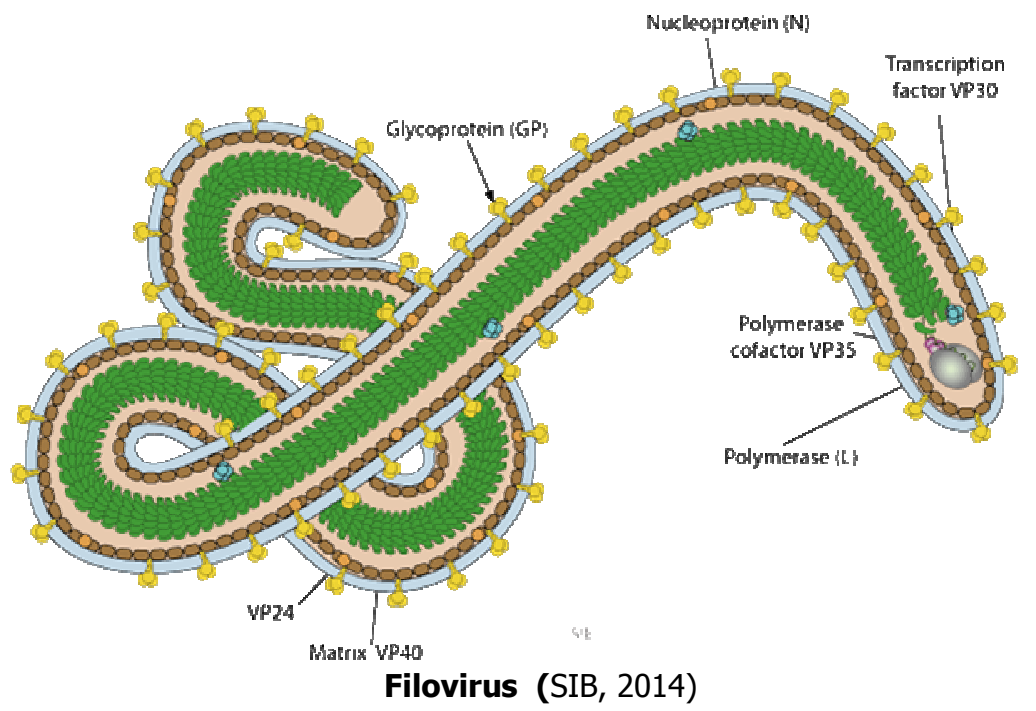


Filoviruses generally possess envelopes and are composed of lipid bilayer covered with polymers. The envelope surrounds a helically wound nucleocapsid (Brooks et al., 2004; WHO, 2012). The genome of Ebola virus consists of single stranded (SS), nonsegmented and negative sense RNA which measures about 19kb in size (Sanchez et al., 1996; Volchkov et al., 1995).

Genus Ebola virus comprises of 5 distinct strains or subtypes that are morphologically similar and share some common epitopes but are antigenically different. These are (i) Ebola virus-Zaire (discovered in DRC) (ii) Ebola-virus-Bundibugyo (Uganda), (iii) Ebola virusReston (USA), (iv) Ebola virus-Sudan (Sudan) and (v) Ebola virus-Tai Forest (Cote d'Ivoire) Jahrling et al., 1990; Miranda et al., 1999; WHO, 2014). It is widely believed that Ebola virus subtypes Zaire and Sudan are the most lethal of all the strains (Feldmann et al., 1996; Sanchez et al., WHO, 2012) causing greater proportion of deaths among the victims (WHO, 2014).

\section{Mode of Transmission of Ebola Virus}

Ebola is primarily a zoonotic disease. It is transmitted to humans from infected wild animals particularly non-human primates including monkeys, chimpanzees and gorillas. Other animals that have been implicated of harbouring EVD include forest antelopes, porcupines and fruit bats; widely believed to serve as natural hosts and reservoirs of Ebola virus following its first detection in bats in 2002 (Fisher-Hoch et al., 1992; Klenk, 1999; WHO, 2003).

Generally, acquisition of EVD by humans is mainly through non-precautionary and non-preventive handling of infected animals or close contract with their bodily fluids including blood, urine, secretions as well as organs and tissue cultures of these animals (CDC, 1990; Sanchez et al., 2001; Sullivan et al., 2013). In human community, secondary spread of EVD among the populace has been found to occur, particularly during the acute phase of the disease via direct contact with the blood, organs, mucous secretions and other body fluids of infected individuals including cadavers or corpses of people who have died from the disease. It is believed that broken skin and mucous membranes play significant role serving as EVD transmission channels. On the other hand, indirect contact with material, equipments and surfaces contaminated with infected human bodily fluids can also serve as sources of infection (WHO, 2014).

Ebola is also recognized as a deadly emerging healthcare-associated infection (HCAI) constituting a serious health hazard to health care workers at all levels of healthcare institutions. Like many other communicable diseases, regular close contact with infected patients is a risk factor that enhances the spread of EVD in the hospital (especially where appropriate infection control/aseptic measures are not practiced or regularly observed), i.e. among patients, healthcare workers and their families.
Men who have been treated and certified free from EVD have been found to still harbor the virus in their semen for upward of 49 days following clinical recovery. Consequently, such individuals have the potential of transmitting the disease via sexual intercourse during this period (Ksiazek et al., 1999a; WHO, 2012).

\section{Risk Factors}

Some of the identified risk factors predisposing individuals to EVD include:

- Handling or close contact with infected animals and their carcasses.

- $\quad$ Consumption of Ebola infected wild animals including fruit bats.

- $\quad$ Close contact and exposure to bodily fluids of infected person(s) especially healthcare workers' family members, relations and close associates who come in contact with EVD patient.

- $\quad$ Touching cadavers shortly after death has occurred and at funerals is considered as an independent risk factor.

- $\quad$ Visit to an area where there is EVD epidemic outbreak without adequate precautionary/preventive measures (WHO, 1978a, b; Baron et al., 1983; Heyman et al., 1980; WHO, 2014).

\section{Processes Leading to Development of Disease in Ebola Virus Infections}

Ebola is a highly pathogenic and aggressively virulent virus. One of the major target sites of infection in human host is the liver causing serious hepatic damage (Riyabchikova et al., 1999; WHO, 2014). It also has predilection for endothelial cells sand mononuclear phagocytes; and can infect other tissues or organs in the body (Baskerville et al., 1985; Feldmann et al., 1996; WHO, 2012). It replicates at an unusually high rate that overwhelms the proteins synthesis apparatus of infected cells and host immune defenses. This characteristic of the virus poses a challenge in the control of infection in human host (Sanchez et al., 2001). All age groups and both sexes are susceptible to Ebola virus infected (WHO, 2003).

Following entry of Ebola virus into human body and subsequent contact with reticuloendothelial cells, cytokines are released which results in nonprotective exaggerated inflammatory responses to the infection (Sullivan et al., 2003). The cells damage arising from direct infection of monocytes and macrophages cause the release of cytokines associated with inflammation and fever. The eventual damage to the liver combined with massive viraemia ultimately results in disseminated intravascular coagulation (DIC). Infection of the microvascular endothelial cells by the virus also induces a cytopathic effect (cell death) which adversely affects vascular integrity and cause damage to the blood vessels resulting in blood leakages. Consequently, there is internal and external bleeding and hypotensive shock and may result in fatality (Sanchez et al., 1996; Colebunder and Borchart, 2000). 


\section{Manifest Signs and Symptoms of Ebola Virus Disease \\ Ebola has rapidly emerged as a severe, acute} haemorrhagic viral illness that is often fatal if untreated early (WHO, 2012). This scenario is further compounded due to the fact that there is no specific clinically certified therapeutic drug or vaccine available till date for the treatment or prevention of Ebola respectively (WHO, 2014).

The incubation period of EVD (i.e. the time interval between exposure to the disease and appearance of the first symptoms) is usually between 2-21 days depending on the immune status of the host (WHO, 2014). EVD initially presents with non-specific flu-like symptoms such as fever, headache, malaise, intense weakness, myalgia and pharyngitis or sore throat. This initial stage may progress to the next stage during which the patient may present with vomiting, diarrhea, rash, impaired kidney and liver functions (Brooks et al., 2004; WHO, 2012). The terminal stage of EVD often manifests in form of diffuse gastrointestinal (internal) and external bleeding from body orifices (including ear, mouth, nose, eyes, etc) and hypotensive shock resulting in organ failure and death (Sandez et al., 1996; Colebunders and Borchart, 2000; WHO, 2014). Laboratory findings often indicate low counts of white blood cells (WBCs) and platelets with elevated transaminase liver enzymes (Ksiazek et al., 1996; WHO, 2003). Ebola virus is known to disrupt important processes that are critical for the activation of immune system and cytolytic-T-cell function. Consequently, there is massive release of cytokines and initiation of exaggerated or unregulated inflammatory responses which are non-protective leading to vascular dysfunction (Zaki et al., 1999b; Sullivan et al., 2003).

In many poor-resourced areas of sub-Saharan Africa where EVD epidemics have occurred for about 4 decades, reliable and effective surveillance, tracking of infection and preventive measures are rarely in place. This poses a challenge in the control of EVD in the sub-region.

Main Methods of Laboratory Diagnosis of Ebola Virus Infection

Although, different types of testing procedures are currently available for the diagnosis of Ebola virus infection (EVI), however, samples collected from infected patient for analysis are known to be extremely bio-hazardous and should be handled with extreme care. It is recommended that such test(s) should be performed under maximum biological containment conditions (Zaki et al., 1999a; WHO, 2012).

Some of the diagnostic methods used for EVIs include:

Enzyme-Linked Immunosorbet Assay (ELISA). It is used for the detection of Ebola virus specific IgG or IgM. Presence of IgM antibody indicates recent infection (Ignatyev, 1999; Ksiazek et al., 1999b).

By virus antigen detection tests in blood, serum or organ (e.g. liver cells) homogenates. This method provides a rapid testing for EVI in human samples (Brooks et al., 2004).

Another useful diagnostic procedure is blood serum neutralization test.

Ebola virus can also be isolated via cell culture using e.g. Vero E6 cells or MA-104 Monkey cell lines including the use of Guinea pigs. The virus isolate is further identified by electron microscopy or direct immunofluorescence.

Molecular test using reverse transcriptase polymerase chain reaction (RT-PCR) assay. It involves virus genome (RNA/DNA) sequencing. The test which amplifies and detects a conserved region of the virus $\mathrm{L}$ gene is highly sensitive and specific (Volchkov et al., 1995; WHO, 2014).

\section{Useful Measures for the Control of Ebola}

Application of measures that may be useful for the control of Ebola viral disease will involve the participation of all segments of the society. These will include the following:

\section{At Personal Level}

Personal hygiene through regular washing of hands with soap and water, or the use of sanitizer (if available and affordable). and outdoors.

Good environmental hygiene-both indoors

- Report case(s) to the nearest healthcare centre for isolation and treatment.

Avoid rumour mongering; it is important for individual to seek for facts about EVD from relevant experts and healthcare personnel.

Institutional Level e.g. Hospital/Care Centres

Strict and prompt barrier isolation of cases in separate area of the hospital for treatment/care.

- Infection risk assessment should be carried out.

- Application of standard universal transmission precaution and barrier nursing including: - Wearing of personal protective equipment (PPE) e.g. gloves, water-resistant apparel/gown, face shield/mask, goggles, disposable cover shoes and respirators.

- Decontamination of hands after contact with patients and wearing of PPE.

- $\quad$ Disinfection of all objects the patient has had contact with including Laboratory materials used for the blood (serological, haematological, molecular, etc) test.

- Decontamination of soiled materials, equipment including vehicles ambulances used to convey the patient or corpse.

- The use of autoclaving, incineration or boiling method as appropriate should be encouraged.

- $\quad$ Formaldehyde fumigation of equipment and isolation rooms/wards etc is desirable in EVD epidemic outbreak.

- $\quad$ The populace should be enlightened about the need to avoid contact with certain bush animals and their body fluids or carcasses e.g. monkeys, gorillas, chimpanzee, porcupines, fruit bats especially in EVD prone area.

- Quarantine close/secondary contacts with Ebola infected patient for surveillance and testing. 


\section{At Government/Other Stakeholders' Level}

This will involve:

Consistent public enlightenment to make sure the general public is safe and remains safe.

Multi-disciplinary and multi-ministerial approach in enlightenment and sensitization campaign throughout the community and nation at large.

Active and responsive surveillance system.

High level discipline among the stakeholders or organizations in the implementation of control strategies.

Provision of required manpower, equipment and logistics by government or donor agencies.

Setting up EVD surveillance committee at all levels of government and institutions.

The need to prevent diminishing response in locating/finding the infected or exposed individuals in the population and quarantine them for surveillance and treatment.

The need to maintain the momentum in the response and management of EVD at all levels of

\section{REFERENCES}

Baron, R.C. McCormic J.B. and Zubeir, O.A. (1983): Haemorrhagic Fever in Southern Sudan: Hospital Dissemination and Intrafamilial Spread. Bull. WHO, 6:997-1003.

Baskerville, A., Fisher-Hoch, S.P., Neild, G.H. and Dowsett, A. B. (1985): Ultra- structural Pathology of Experimental Ebola Haemorrhagic Fever Virus Infection, $J$. Pathol. 147:199-209.

Bowen, E. T., Lloyed, G., Harris, W.I., Platt, G.S., Baskerville, A., and Vella, E.E. (1977): Viral Haemorrhagic Fever in Southern and Northern Zaire: Preliminary Studies on the Aetiologic Agent, Lancet 1:571-573.

Brooks, G. F., Butel, J.S. and Morse, S.A. (2004): African Haemorrhagic Fevers, Marburg and Ebola Viruses In: A Larnge Medical Book, Jawets, Melnick and Aldeber's Medical Microbiology.23 ${ }^{\text {rd }}$ edition, McGraw Hill Publishers, Boston. Pp. 533-535.

Centers for Disease Control and Prevention (1990): Update: Filovirus Infection in Animal Handlers, MMWR 39:221-223.

Colebunders, R. and Borchart, M. (2000): Ebola Haemorrhagic Fever-A Review. J. Infect. 40:16-20.

Colebunders, R., and Borchart, M. (2000): Ebola Haemorrhagic Fever- A Review. J. Infect. 40: 16-20.

Epainassist

www.epainassist.com/infection/ebola-virus Retrieved 12th March, 2015.

Federal Ministry of Health (2014): Report on Ebola Outbreak: Update. Federal Ministry of Health, Abuja-Nigeria.

Feldmann, H., Bugany H., Mahner, F., Klenk, H.D., Drenckhahn, D, and Schnittler, H. J. (1996): Filovirus-Induced Endothelial Leakage Triggered by Infected Monocytes/Macrophages. J. Virol. 70:22082214. government and populace until EVD is controlled (Fisher-Hoch et al., 1992; Ksiazek et al., 1996; Georges et al., 1999; WHO, 2003; WHO, 2012, WHO, 2014.

\section{Conclusion/Recommendation}

Although EVD appears to be on the fast lane running ahead of human race in its game in terms of the latter's inability to produce clinically certified therapeutic agent or vaccine against the disease hitherto, but despite the present scenario, it is still possible to slow down the deadly disease, catch up with it and even defeat it in no distant future. Therefore, there should be a renewed commitment and unwavering efforts by all stakeholders (e.g. scientists, drug/vaccine manufacturers, organizations, health care workers, governments, general public etc) geared toward doing the needful necessary to put an end to EVD scourge and its devastating socioeconomic impact in sub-Saharan Africa and indeed globally where the EVD outbreak may occur.

Feldmann, H., Nichol, S.T. Klenk, H.D., Peters, C.J. and Sanchez,A. (1994): Characterisation of Filoviruses Based on Differences in Structures and Antigenicity of the Virion Glycoprotein. Virology 199:469-473.

Fisher-Hoch, S.P., Brammer, T.L., and Trappier, S.G. et al., (1992): Pathogenic Potential of Filovirus: Role of Geographic Origin of Primate Host and Virus Strain. J. Infect. Dis. 166:753-763.

Formenty, P., Hutz, C., LeGuenno, B.O. Stoll, A., Rogenmoser, P. and Widmer, A.(1999): Human Infection due to Ebola Virus Subtype Cote d'Ivoire: Clinical and Biologic Presentation. J. Infect. Dis. 179 (Suppl. 1): S48-S53.

Georges, A. J., Leroy, E.M., Reaut, A.A.et al. (1999): Ebola Haemorrhagic Fever Outbreaks in Gabon. 1994-1997: Epidemiology and Health Control Issues. J. Infect. Dis. 179 (Suppl. 1): S65-S75.).

Heymann, D. L., Weisfeld, J.S., Webb, P.A., Johnson, K.M. and Cairns-Berquist, H. (1980): Ebola Haemorrhagic Fever, Tandala Zaire, 19771978. J. Infect. Dis. 142:372-376.

http//www.who/c:/users/dr9519-22015_02_01/en/, Retrieved 30 $0^{\text {th }}$ March, 2015.

Ignatyev, G.M. (1999): Immune Response to Filovirus Infection. Curr. Top. Microbiol. Immunol. 235:205-217.

Jahrling, P.B., Geisbert, T.W., Dalgard, D.W., Johnson, E.D. Ksiazek, T.G., Hall, W.C. and Peters, C. J. (1990): Preliminary Report: Isolation of Ebola Virus from Monkeys Imported to USA. Lancet. 335:502-505.

Johnson, K.M., Lange, J.V., Webb, P.A. and Murphy, F.A. (1977); Isolation and Partial Characterization of a New Virus Causing Acute Haemorrhagic Fever in Zaire. Lancet. i:569-571.

Klenk, H.D. (1999): Marburg and Ebola Viruses, Curr. Top Microboil. Immunol. 235:1-217. 
Ksiazek, T.G., Rollin, P.E. and Williams, A. J. (1999b): Clinical Virology of Ebola Haemorrhagic Fever (EHF): Virus, Virus Antigen, and IgG and IgM Antibody Findings among EHF Patients in Kikwit, Democratic Republic of Congo. J. Infect. Dis. 179 (Suppl. 1): S177-S187.

Miranda, M.E., Ksiazek, T.G. and Retuya, J.J. et al. (1999): Epidemiology of Ebola (Subtype Reston) Virus in the Phillipines. J. Infect. Dis. 179 (Suppl.1):S115-S119.

Peters, C.J. and LeDuc, J. W. (1999); Ebola: The Virus and Disease. J. Infect. Dis. 179 (Suppl. 1): S1-S19.

Ryabchikova, E.I. Kolesnikova, L.V. and Luchko, S. V. (1999): An Analysis of Features of Pathogenesis in Two Animal Models of Ebola Virus Infection. J. Infect. Dis. 179 (Suppl.1): S199-S202.

Sanchez, A., Khan, A.S., Zaki, S.R., Nabel, G.J., Ksiazek, T.G. and Peters, C.J. (2001): Filoviridae: Marburg and Ebola Viruses In: Fields Virology, D.M. Knipe and P.M. Howley (Editors), Lippincolt Williams and Wilkins Publ. Philadelphiapa, Pp. 1279-1304.

Sanchez, A., Trappier, S. G., Mahy, B.W.J., Peters, C.J. and Nichol, S.T. (1996): The Virion Glycoprotein of Ebola Viruses are Encoded in Two Reading Frames and Expressed through Transcriptional Editing. Proc. Natl. Acad. Sci. USA. 93: 3602-3607.

Sullivan, N., Yang, Z. Y. and Nabel, G. (2013): Ebola Virus Pathogenesis: Implications for Vaccines and Therapy. Nature: 424:681-684.

Swiss Institute of Bioinformatics (2014): Viralzone.expasy.org/all_by_ species/207.html. Retrieved $15^{\text {th }}$ April, 2014.
United Nation Children and Educational Fund (2015): Ebola Virus Disease Update UNICEF, 1-4.

Volchkov, V.E., Becker, S., Volchkova, V.A., Ternovoj, V.A., Kotov, A.N., Netesov, S.V. and Klenk, H.D. (1995): Gp mRNA of Ebola Virus is Edited by the Ebola Virus Polymerase and by T7 and Vaccinia Virus Polymerase. Virology, 214:421-430.

World Health Organization (1978a): Ebola Haemorrhagic Fever in Sudan, 1976. Report of World Health organization International Study Team. Bull. WHO 6: 247-270.

World Health Organization (1978b): Ebola Haemorrhagic Fever in Zaire, 1976. Report of International Commission. Bull. WHO. 56:271-293.

World Health Organization (2003): Ebola Virus Outbreaks in Central Africa. http://www.who.int/csr/don/2003_05_07.Ret rieved $22^{\text {nd }}$ June, 2003.

World Health Organization (2012): Ebola Haemorrhagic Fever. htt://www.who.int/mediacentre/factsheets/fs /103/en/index.html. Retrieved $3^{\text {rd }}$ February, 2014.

World Health Organization (2015): Ebola Virus Disease Update.

Zaki, S. R., Goldsmith, C.S. (1999b): Pathologic Features of Filovirus Infections in Humans. Curr. Trop. Microbiol. Immunol. 235: 97-116.

Zaki, S.R., Shieh, W., Greer, P.W. et al., (1999a): A Novel Immune Histochemical Assay for the Detection of Ebola Virus in Skin: Implications for Diagrams, Spread and Surveillance of Ebola Haemorrhagic Fever. J. Infect. Dis. 179: S36-S47. 